\title{
Nutritional and hormonal control of gut epithelium remodeling in neonatal piglets*
}

\author{
R. Zabielski ${ }^{1,2,4}$, D. Laubitz ${ }^{1}$, J. Woliński ${ }^{1}$ and P. Guilloteau ${ }^{3}$ \\ ${ }^{1}$ The Kielanowski Institute of Animal Physiology and Nutrition, Polish Academy of Sciences \\ 05-110 Jabtonna \\ ${ }^{2}$ Warsaw Agricultural University, \\ Department of Physiological Sciences, Faculty of Veterinary Medicine \\ Nowoursynowska 159, 02-776 Warsaw, Poland \\ ${ }^{3} U M R-S E N A H$, Institut National Recherche Agronomique \\ 35-590 Saint-Gilles, France
}

\begin{abstract}
The first days of life are crucial for the development of intestinal mucosa in mammalian neonates. Its development consists of tissue growth and maturation, in particular of the epithelium. During postnatal development, the first $24 \mathrm{~h}$ are the most important, as this is when intensive remodeling of epithelial cells linked with cell replacement and functional modification occurs. An infant's small intestine adapts to new digestive functions and feed. In this period, luminal and systemic hormones and growth factors play an important role. Sow colostrum and milk contain a high concentration of hormones and growth factors stimulating growth and maturation of small intestinal mucosa. Feeding animals milk formulas devoid of these bioactive factors slows down intestinal maturation in comparison with natural feeding by the mother. Recent studies demonstrate the great impact of nutritional, hormonal, paracrine and autocrine factors on epithelial cell proliferation and differentiation processes.
\end{abstract}

KEY WORDS: growth, maturation, intestinal mucosa, enterocytes

\section{INTRODUCTION}

In mammalian neonates, the mucosa of the small intestine undergoes intensive development which is particularly fast during the first few days of

\footnotetext{
${ }^{*}$ Supported by the State Committee for Scientific Research, Grant No. PBZ-KBN-093/P06/2003

${ }^{4}$ Corresponding author: e-mail: rzabielski@plusnet.pl
} 
postnatal life. Development consists of both growth and maturation of the gut, resulting in modification of its structure and function. In the early postnatal period, mucosa growth is manifested by increased gut size and weight, whereas maturation is associated with profound tissue remodeling, i.e. with programmed exchange of cell populations leading to a modification of gut digestive function (Biernat, 2002; Woliński, 2003; Table 1, Figure 1). The remodeling concerns mostly the epithelial cells. The neonatal pig is often used as an animal model to study the development of gastrointestinal (GI) tract mucosa. Economy is one of reasons, since the preweaning mortality in piglets is relatively high and ranges from 40 to $7 \%$ for animals with a birth weight less than $1 \mathrm{~kg}$ and over $1.6 \mathrm{~kg}$, respectively (Roeche, 1999). A substantial percentage of these piglets die due to GI dysfunctions, thus any reduction in these statistics would be beneficial for the pig industry. There is also increasing interest in using the pig gut as a model for human babies, owing to a number of similarities between pig and human GI tract structure and function. Studies in piglets are also promising for evaluation of novel artificial milk formulas for human babies, in particular preterm neonates. In recent years, extensive research on the development of gut function has been conducted. In the present article we attempt to concentrate on the rebuilding of the gut epithelium in the early postnatal period, which is crucial for gut closure and maturation of digestive function of the neonate.

\section{POSTNATAL DEVELOPMENT OF THE GUT MUCOSA IN NEONATAL PIGS}

\section{Intestinal mucosa growth}

In the neonatal pig, growth of the small intestine is evidenced by an increase in the size and weight of the intestine, mainly of the intestinal mucosa. These changes are related to feeding colostrum since no changes were observed when the piglets received water (Widdowson et al., 1976). During the first 24 postnatal hours, the body weight increased by about $15 \%$, whereas the length and weight of the small intestine increased by 24 and 70\%, respectively (Xu et al., 1992). In the same study, the size of intestinal villi and crypts increased by 24 and $33 \%$, respectively. The increase in intestinal weight is associated with an increase in villous length, both in premature pig neonates, and those born at term (Petersen et al., 2003). Bottle feeding of colostrum or trypsinized colostrum, but not lactose solution, led to an increase in the weight and length of the small intestine and mucosa protein content. The total contents of the small intestinal mucosa of piglets fed the first two regimens were 39 and $64 \%$ greater, respectively, than in newborn, unsuckled piglets (Wang and $\mathrm{Xu}, 1996$ ). In terms of growth during 
the first week of life, in the study by Woliński et al. (2003), sow-reared piglets doubled their body weight as compared with unfed neonates, but the length of the small intestine was increased by $75 \%$, and that of intestinal crypts and villi, by 24 and $30 \%$, respectively. This comparison suggests that the most dynamic growth of the gut mucosa occurs during the first few postnatal days of pig life. Nevertheless, when considering the kinetics of changes, it is still far from the extremes found in the intestines of re-fed pythons and hibernating mammals following a long period of starvation (Secor and Diamond, 1995; Pennisi, 2005). Like in re-fed adult snakes, the absorptive capacity of intestinal mucosa and the total activity of brush border enzymes significantly increase in the intestinal mucosa of pig neonates, thus enhancing the digestion of feed and absorption of nutrients (Zhang et al., 1997).

Several studies addressed the way by which neonates can achieve such a high dynamic of intestinal mucosa growth in a relatively short time. Simmen et al. (1990) found that pig neonates fed with colostrum and milk had heavier intestines than those fed with lactose. The total protein content in the intestinal mucosa of the colostrum- or milk-fed piglets was higher by 67 and 45\%, respectively, as compared with lactose-fed piglets. In addition, Tungthanathanich et al. (1992) and Woliński et al. (2003) demonstrated that feeding cow colostrum and milk, as well as artificial milk formulas, resulted in poorer growth of the small intestine than when sow colostrum was fed. According to Biernat (2002), the growth of intestinal mucosa depends on milk intake by pig neonates; piglets receiving more milk had heavier intestines with longer villi, and enterocytes with larger lysosomal vacuoles, but no important effects on the maturation of epithelial cells were found. Burrin et al. (1992) suggested that the increase in intestinal mucosa weight in the early postnatal period is related to the accumulation of colostrum proteins rather than to enhanced proliferation in crypt stem cells. In contrast, Zhang et al. (1997) showed that in sow-reared piglets, the DNA content increased during the first postnatal hours as a result of enhanced mucosal stem cell proliferation, which may explain mucosa growth. Our recent studies consistently suggest that during the first few postnatal days, the increased cell proliferation in the intestinal crypts is associated with a marked reduction in the apoptosis of epithelial cells in the intestine, thereby doubling the mitosis/apoptosis ratio (Biernat et al., 2003; Table 1). Finally, the mucosa growth in pig neonates is associated with a substantial increase in local intestinal blood flow, concurrently with a reduction in basal vascular resistance (Nankervis et al., 2001). The haemodynamic changes may appear rapidly after the first colostrum suckling and do not need much energy input. In summary, intensive growth of the mucosa in the early postprandial period is the combined effect of haemodynamic changes and protein accumulation in the gut mucosa, as well as a shift toward mitoses in the cell proliferation/apoptosis balance in the intestinal epithelium. 
Table 1. Body weight $(\mathrm{kg})$, small intestine length $(\mathrm{cm})$, mitotic index, percentage of vacuolated enterocytes $(\%)$ and brush border enzyme activity ( $\mu \mathrm{moles} / \mathrm{min} / \mathrm{g}$ mucosa) in non suckling and sow reared new born piglets

\begin{tabular}{lclcc}
\hline Piglets & At birth & After 1 day & After 7 days & $\mathrm{P}$ \\
\hline Body weight, kg & $1.34 \pm 0.12^{\mathrm{a}}$ & $1.75 \pm 0.06^{\mathrm{a}}$ & $3.38 \pm 0.52^{\mathrm{b}}$ & $\mathrm{P}<0.0001$ \\
Small intestine length, cm & $286 \pm 34^{\mathrm{a}}$ & $389 \pm 23^{\mathrm{b}}$ & $499 \pm 32^{\mathrm{c}}$ & $\mathrm{P}<0.0001$ \\
Mitotic index, mid jejunum & $2.77 \pm 0.15^{\mathrm{a}}$ & $4.68 \pm 0.09^{\mathrm{b}}$ & $5.18 \pm 0.32^{\mathrm{c}}$ & $\mathrm{P}<0.0001$ \\
\% LV, mid jejunum & - & $32.5 \pm 10,8$ & - & - \\
Lactose & $24.8 \pm 1.3^{\mathrm{a}}$ & $12.8 \pm 3.2^{\mathrm{b}}$ & $10.6 \pm 1.8^{\mathrm{b}}$ & $\mathrm{P}<0.0001$ \\
Maltase & $0.62 \pm 0.13^{\mathrm{a}}$ & $2.18 \pm 0.74^{\mathrm{a}}$ & $7.37 \pm 2.20^{\mathrm{b}}$ & $\mathrm{P}=0.0006$ \\
Sucrase & $0.25 \pm 0.10^{\mathrm{a}}$ & $0.84 \pm 0.67^{\mathrm{a}}$ & $2.59 \pm 0.76^{\mathrm{b}}$ & $\mathrm{P}=0.012$ \\
Aminopeptidase A & $9.18 \pm 0.74^{\mathrm{a}}$ & $5.33 \pm 0.53^{\mathrm{b}}$ & $10.4 \pm 1.4^{\mathrm{a}}$ & $\mathrm{P}=0.0005$ \\
Aminopeptidase N & $6.18 \pm 0.41^{\mathrm{a}}$ & $4.33 \pm 0.72^{\mathrm{b}}$ & $1.67 \pm 0.36^{\mathrm{c}}$ & $\mathrm{P}=0.0001$ \\
Dipeptidase IV & $0.99 \pm 0.25^{\mathrm{a}}$ & $0.99 \pm 0.14^{\mathrm{a}}$ & $1.92 \pm 0.43^{\mathrm{b}}$ & $\mathrm{P}=0.01$ \\
\hline
\end{tabular}

values are given as means \pm SEM $(n=6)$. Different letters indicate statistical significance (one-way ANOVA followed by Tukey post ANOVA test)

\section{Maturation of intestinal mucosa}

The maturation of intestinal mucosa is associated with remodeling of epithelial cells. This may be achieved either by modification of enterocyte functions during their short life-time on the crypt and villi, and/or by changes resulting from a fast proliferation rate, differentiation in the intestinal crypt area, and replacement of old epithelial cells by new generations. The successor cells may differ in the expression of a set of cell proteins, for instance in the composition of membrane receptors, brush border enzymes and transporter proteins. It is well known that full replacement in mucosa cell generation lasts only a few days (Lipkin et al., 1963; Bell et al., 1967). Recent studies showed that the most intensive changes occur within a first $24 \mathrm{~h}$ after birth. Biernat et al. (2003) showed that in sow-reared piglets, within 2 days after birth crypt cell proliferation significantly increases concomitantly with the decrease in the number of cells undergoing apoptosis, resulting in rapid enhancement of the number of epithelial cells. In 7-day-old pigs, this phenomenon was not observed. The increase in the mitotic index is associated with augmented cell differentiation into enterocytes, goblet, endocrine and immune cells (Zhang et al., 1997). Goblet cells are one of the first differentiated cells in the intestinal epithelium, in pigs they appear in the middle of gestation (Sanglid et al., 2002). The relative number of goblet cells increases along the small intestine, and changes along with age-the trace numbers in newborns rapidly increase around weaning; this can be used as a marker to assess intestinal maturity (Bardocz et al., 1999). Modification in enterocyte structure and function, like the disappearance of large lysosomal vacuoles, has a significant impact on intestinal maturation (Figure 1). 


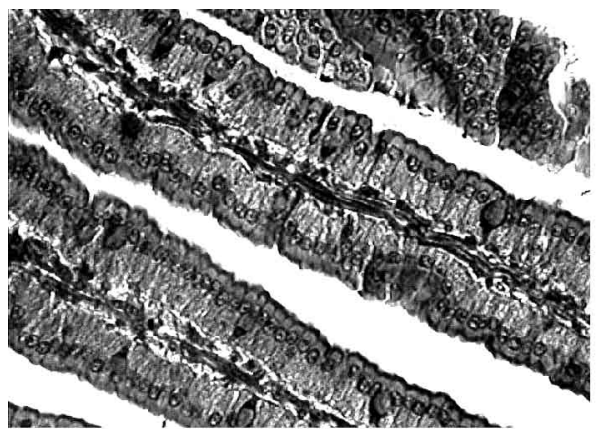

(C0)

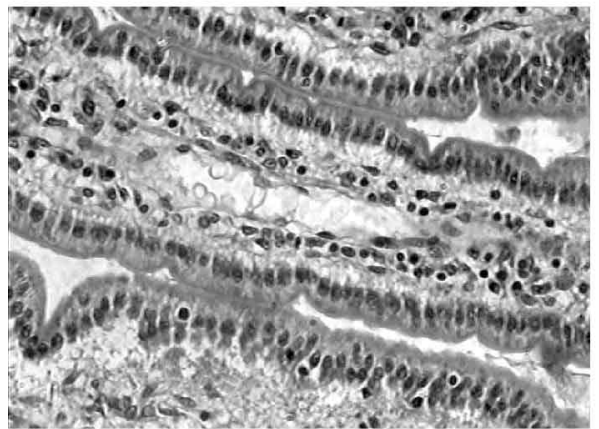

(C7SR)

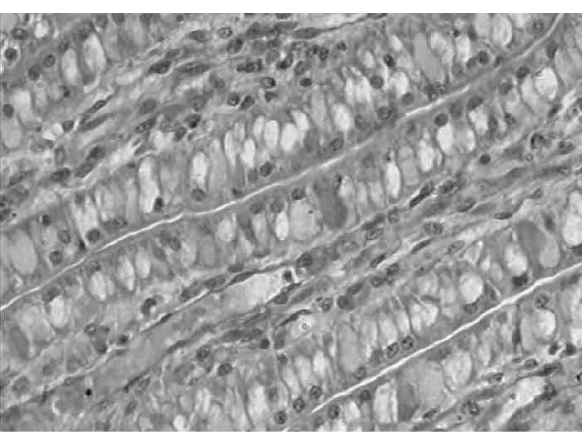

(C24)

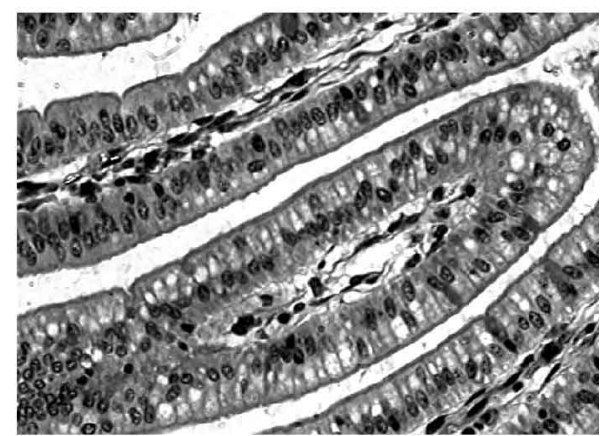

(C7)

Figure 1. The small intestinal villi in the mid jejunum of newborn unsuckling piglets $(\mathrm{C} 0)$, sow reared piglets for $24 \mathrm{~h}(\mathrm{C} 24)$ and 7 days (C7SR) and fed for 7 days with artificial milk formula. Enterocytes containing lysosomal vacuoles are present in suckling neonates (C24) as well as in piglets fed with milk formula but not in sow reared piglets (Magnification 50x)

The vacuoles participate in macromolecule transport via the enterocyte and support digestive processes. In pigs, the vacuoles disappear in the duodenum just after birth, in the proximal jejunum after 1-2 days, in the middle and distal jejunum, after about 2 weeks, and in the ileum, after about 4 weeks after birth (Baitner, 1994, 2002). The disappearance of lysosomal vacuoles can be used as a marker of mucosa maturation since the timing is so precise (Radberg et al., 2001; Biernat, 2002; Woliński et al., 2003). Gut closure in pigs coincides with replacement of "foetal type" vacuolated enterocytes into "adult type" enterocytes devoid of the ability to generate transport vacuoles. The activity of brush border enzymes changes with age (Sanglid et al., 1999). In newborn pigs and calves, a high level of lactase is observed, especially in the proximal part, which decreases in time. A similar pattern was observed in the activity of endopeptidase. Maltose and sucrase activities are initially very low and increase with age. These enzymes 
are secreted mainly in the proximal and middle jejunum. Aminopeptidases A and $\mathrm{N}$, and dipeptidase IV are synthesized along the small intestine, with the highest activity in the distal part of the small intestine (Manners and Stevens, 1972; LeHuerou et al., 1992; Torp et al., 1993).

\section{HORMONAL REGULATORS OF GUT EPITHELIAL MATURATION}

In the neonatal period, systemic and luminal hormones and growth factors play an important role in the development of the small intestine. Systemic, adrenocortical hormones control the maturation of the intestine, in particular during the prenatal period (Trahair and Sangild, 1997). The peculiarity in mammalian species is the contribution of growth factors and hormones present in colostrum and milk, which following ingestion retain their biological activities and act either from the lumen or after being absorbed. Intestinal absorption of several bioactive peptides, including insulin (Ziv and Bendayan, 2000) is currently considered a normal physiological process. On the other hand, recent studies with systemic growth hormone administration in neonatal pigs resulted in $60 \%$ inhibition of glucose and amino acid absorption from the small intestine (Fholenhag et al., 1999). These two examples somehow undermine earlier dogmas, and illustrate the complexity of the regulation of intestinal epithelium function. In the present paper we mention only a few growth factors and hormones among those present in colostrum and milk.

Sow colostrum and milk contain high concentrations of epidermal growth factor (EGF), enough to control the development of the intestinal mucosa in newborn pigs. EGF receptors are localized on the epithelial cells with the greatest concentration of EGF binding sites in the intestinal crypts (Menard and Pothier, 1991). The EGF receptor is predominantly located on the enterocyte basolateral membrane, although part of it may be redistributed to the brush border membrane (Avissar et al., 2000). In suckling pigs the density of EGF receptors is lower than in weaned pigs (Kelly et al., 1992).

EGF is known to stimulate mitoses, and enhance maturation of intestinal epithelial cells (Read et al., 1984). In adult rabbits, EGF inhibits apoptosis in the intestinal crypts induced by octreotide, a somatostatin analogue. In contrast, apoptosis in the villi was unaffected by EGF (Thompson, 1999). Using the mouse small intestine resection model Helmrath et al. (1998) showed that oral EGF may serve a dual function of stimulating enterocyte proliferation and inhibiting enterocyte apoptosis, thereby enhancing the half-life of newly produced enterocytes. Using the rat intestine resection model, Jarboe et al. (2005) demonstrated that EGF receptor signalling is associated with crypt cell differentiation into goblet cells and absorptive enterocytes. Besides affecting 
maturation, luminal application of EGF rapidly increases the brush border surface area, and enhances enterocyte glucose and proline uptake (Hardin et al., 1993, 1996).

In the pig gut, two types of insulin-like growth factor (IGF) receptors were identified: type I, which preferentially binds IGF-I rather than IGF-II and insulin, and type II that binds IGF-II but not insulin (Schober et al., 1990; Morgan et al., 1996). Oral administration of IGF stimulates growth and maturation of the small intestine and its digestive function, however, most studies were performed with pharmacological doses. In contrast to pharmacological doses, low doses of IGF-I do not affect the weight and size of the small intestine or its DNA and protein contents (Burrin et al., 1996). However, brush border enzyme activities (e.g., lactase phlorizin hydrolase activity and the corresponding mRNA content) and villi length are increased in comparison with piglets receiving milk formula without IGF-I (Houle et al., 1997, 2000). In colostrum-deprived neonatal piglets, oral administration of IGF-I increased basal $\mathrm{Na}^{+}$and $\mathrm{Na}^{+}$-dependent nutrient (D-glucose, L-alanine, Lglutamine) absorption by a mechanism independent of changes in mucosal mass or surface area (Alexander and Carey, 1999, 2002). Stimulation of the maturation of intestinal mucosa by IGF-I was also observed in neonatal rats (Ma and $\mathrm{Xu}$, 1997; Staley et al., 1998) and calves (Baumrucker et al., 1994). In newborn mice, IGF-I accelerates epithelial cell migration, and Gordon et al. (2004) suggested that IGF-I can mediate the maturation effects of steroids. The role of milk-borne IGF-I has been questioned in rats and humans since newborns are capable of producing sufficient amounts of IGF-I (Burrin, 1997; Steeb et al., 1997). Experiments on calf neonates showed, however, that plasma IGF-I concentrations depend on the amount and timing of colostrum ingestion (Blum and Hammon, 2000).

Sow colostrum and milk, in particular during the first few days of lactation, contain large concentrations of insulin that are many times higher than the concentrations in the blood plasma of sow and offspring (Weström et al., 1987). Oral insulin $(85 \mathrm{mU} / \mathrm{ml})$ enhanced growth of the intestine and increased the activity of brush border lactase and maltase in pig neonates fed with milk formula (Shulman et al., 1992). Partial supplementation of milk formula with IGF-I delayed the maturation of pig gut mucosa, but to a lesser degree than in pigs fed non-supplemented formula (Biernat, 2002). Systemic insulin is also considered an important regulator of macromolecule absorption and gut closure (Svendsen et al., 1986; Read, 1988). This also applies to the milk-born hormone after it is absorbed (Ziv and Bendayan, 2000). Interestingly, Kojima et al. (1998) demonstrated that insulin receptors appeared transiently on the enterocyte surface during the early G1 phase following IGF-I stimulation. This induced an autocrine/ paracrine secretion of transforming growth factor- $\beta 1$ (TGF- $\beta 1$ ) that in turn antagonized the mitogenic effects of IGF-I. In the intestinal mucosa, a gradient of mRNA transcripts encoding TGF- $\beta$ is maintained along the crypt-villus axis 
in correlation with the stage of differentiation of the enterocyte (Lamprecht et al., 1989). Confocal microscopy of the neonatal pig mucosa with TGF- $\beta 1$ antibodies confirms the previous findings (Godlewski et al., 2005). These results suggest that the regulation of cell proliferation is controlled by a complex of luminal, local and systemic factors induced by nutrient intake.

Glucagon-like peptide-2 (GLP-2), secreted by the endocrine L-cells, is considered an important regulator of growth and maturation of the small intestinal mucosa that enhances stem cell proliferation and simultaneously reduces programmed cell death in neonatal piglets (Burrin et al., 2005). In this study, physiological doses of GLP-2 reduced apoptosis as confirmed by the decrease in caspase- 3 and -6 levels and induction of Bcl-2 expression, thereby stimulating intestinal cell survival. GLP-2 stimulates cell proliferation in GI mucosa, leading to expansion of the normal mucosal epithelium, or attenuation of intestinal injury in experimental models of intestinal disease (Drucker, 2003). Maturation effects of GLP-2 are manifested by modifications in brush border enzyme activities and membrane protein transporters (Burrin et al., 2003; Petersen et al., 2003). In refed mice, physiological doses of GLP-2 regulated the dynamic adaptation of the gut mucosal epithelium in response to luminal nutrients (Shin et al., 2005).

We have demonstrated that leptin is present in sow colostrum and milk in doses many-fold higher than in sow and piglet blood plasma, whereas milk formulas contain little leptin (Woliński et al., 2003). In milk-formula-fed neonatal piglets, leptin supplementation did not affect body or gastrointestinal organ weights, the structure of the stomach or pancreas, but it did increase intestinal crypt depth in the upper jejunum, reduce intestinal villi length and the number of vacuolated enterocytes as well as the size of lysosomal vacuoles, and increase the mitotic index. Moreover, it reduced lactase, sacharase and maltase activity in the entire jejunum as well as the in vivo absorption of a marker molecule-bovine serum albumin (Woliński et al., 2003). Leptin administration also affected spontaneous and acetylcholine-induced intestinal motor activity in vitro (Woliński et al., 2001). These results suggest that leptin given into the gastrointestinal tract lumen speeds up the maturation of the small intestinal mucosa, causing strong proliferation of crypt stem cells with simultaneous reduction of apoptosis, as evidenced by the abundance of caspase-3 and -8 (Woliński et al., 2003; Godlewski et al., 2005).

Ghrelin was discovered as a 28 -amino-acid endogenous ligand of the growth hormone secretagogue receptor (GHS-R) (Koijma et al., 1999) with the noctanolyl group in $\mathrm{Ser}^{3}$ that is decisive for its biological activity (Bowers, 2001; Banks et al., 2002). Ghrelin is known as a regulator of an array of endocrine and nonendocrine functions, including, food intake (Torsello et al., 1998; Hosoda et al., 2002), energy homeostasis (Tannenbaum et al., 2003) and cell proliferation (Barreiro et al., 2004). In adults, exogenous ghrelin exerts cytoprotective activity on the stomach mucosa (Sibilai et al., 2003) and pancreas (Dembinski et al., 
2003). To our knowledge no information is available on the participation of ghrelin in the development of gastrointestinal mucosa. This can be deduced from the following information. The level of synthesis of gastric ghrelin increases from birth to weaning and then dramatically decreases both in rats and mice (Sakata et al., 2002). Moreover, the ratio of the acylated form to total ghrelin increases in the suckling period (Fugslang et al., 2005; Yoshihiro et al., 2005). Our recent RIA study points to the presence of ghrelin in sow colostrum and milk in concentrations higher than in the sow's and offsprings' blood plasma (Woliński et al., unpublished data). It is difficult to speculate, however, on the role of ghrelin in the maturation of gut mucosa, since the influence of this peptide on cell proliferation depends on the tissue. On the one hand, exogenous ghrelin inhibits angiogenesis in vitro and in vivo (Conconi et al., 2004), and reduces the proliferative activity of differentiating immature Leydig cells (Barrerio et al., 2004). On the other hand, ghrelin stimulates osteoblast proliferation in vitro in primary cultures of rat calvaria (Maccarinelli et al., 2005).

\section{CONCLUSIONS}

The precise relationships between the hormonal and nutritional influences after birth on the one hand and the developmental program of the gut on the other are unclear. Although the genetic program seems to play a predominant role in the perinatal period, the data accumulated so far indicate that the inauguration of enteral nutrition plus the milk-borne and endogenous bioactive substances such as hormones and growth factors, significantly contribute to the maturation of gut mucosa after birth. This review emphasizes that milk-borne hormones and growth factors provide important maturation signals to the neonatal intestine toward enhanced epithelial cell remodeling. The maturation of gastrointestinal tissues is closely associated with the viability of the neonate, and it is also suggested to be linked with further health and productivity. Thus, a number of hormones and growth factors may be useful tools for controlling cell differentiation, tissue regeneration and cytoprotection in treating a number of gastrointestinal disorders in neonates. Moreover, formulation of new milk replacers should involve a number of protein/peptide factors of established biological activity.

\section{REFERENCES}

Alexander A.N., Carey H.V., 1999. Oral IGF-I enhances nutrient and electrolyte absorption in neonatal piglet intestine. Amer. J. Physiol. 277, G619-G625

Alexander A.N., Carey H.V., 2002. Insulin-like growth factor-I stimulates Na+-dependent glutamine absorption in piglet enterocytes. Digest. Dis. Sci. 47, 1129-34 
Avissar N.E., Wang H.T., Miller J.H., Iannoli P., Sax H.C., 2000. Epidermal growth factor receptor is increased in rabbit intestinal brush border membrane after small bowel resection. Digest. Dis. Sci. 45, 1145-1152

Baintner K., 1994. Demonstration of acidity in intestinal vacuoles of the suckling rat and pig. J. Histochem. Cytochem. 42, 231-238

Baintner K., 2002. Vocoulation in the young. In: R. Zabielski, P.C. Gregory, B.R. Weström (Editors). Biology of the Intestine in Growing Animals. Elsevier, Amsterdam (The Netherlands), pp. 55110

Banks W.A., Tschop M., Robinson S.M., Heiman M.L., 2002. Extent and direction of ghrelin transport across the blood-brain barrier is determined by its unique primary structure. J. Pharmacol. Exp. Ther. 302, 822-827

Bardocz S., Grant G., Puszta A., Swen S.W.B., 1999. Lectins as a gut growth factors - a sumary. In: COST '98 (Editor). Effects of Antinutrients on the Nutritional Value of Legume Diets. Vol. 6, 61-64

Barreiro M.L., Gaytan F., Castellano J.M., Suominen J.S., Roa J., Gaytan M., Aguilar E., Dieguez C., Toppari J., Tena-Sempre M., 2004. Ghrelin inhibits the proliferation of immature leydig cells in vivo and regulates stem cell factor messenger ribonucleic acid expression in rat testis. J. Endocrinol. 145, 4825-4835

Baumrucker C.R., Hadsell D.L., Blum J.W., 1994. Effects of dietary insulin-like growth factor I on growth and insulin-like growth factor receptors in neonatal calf intestine. J. Anim. Sci. 72, 428 - 433

Bell B., Almy T.P, Lipkin M., 1967. Cell proliferation kinetics in the gastrointestinal tract of man.Cell renwal in esophagus, stomach and jejunum of a patients with treated pernicious anemia. J. Nat. Cancer Inst. 41, 361-389

Biernat M., 2002. Factors controlling growth and maturation of the porcine small intestinal structure and function in an early postnatal period (in Polish). PhD. Thesis. The Kielanowski Institute of Animal Physiology and Nutrition Polish Academy of Sciences, Jabłonna

Biernat M., Woliński J., Godlewski M.M., Motyl T., Morisset J., Zabielski R., 2003. Apoptosis in the gut of neonatal piglets. Proceedings of the $9^{\text {th }}$ International Symposium on Digestive Physiology in Pigs, University of Alberta, Edmonton, pp. 46-48

Blum J.W., Hammon H., 2000. Colostrum effects on the gastrointestinal tract, and on nutritional, endocrine and metabolic parameters in neonatal calves. Livest. Prod. Sci. 66, 151-159

Bowers C.Y., 2001. Unnatural growth hormone-releasing peptide begets natural ghrelin. J. Clin. Endocrinol. Metab. 8, 1464-1469

Burrin D.G., 1997. Is milk-borne insulin-like growth factor-I essential for neonatal development? J. Nutr. 127, 975S-979S

Burrin D., Guan X., Stoll B., Petersen Y.M., Sangild P.T., 2003. Glucagon-like peptide 2: a key link between nutrition and intestinal adaptation in neonates? J. Nutr. 133, 3712-3716

Burrin D.G., Shulman R.J., Reeds P.J, Davis T.A., Gravitt K.R., 1992. Porcine colostrums and milk stimulate visceral organ and skeletal muscle protein synthesis in neonatal piglets. J. Nutr. 122, $1205-1213$

Burrin D.G., Stoll B., Guan X., Cui L., Chang X., Holst J.J., 2005. Glucagon-like peptide 2 dosedependently activates intestinal cell survival and proliferation in neonatal piglets. Endocrinology 146, 22-32

Burrin D.G., Wester T.J., Davis T.A., Amick S., Heath J.P., 1996. Orally administered IGF-I increases intestinal mucosal growth in formula-fed neonatal pigs. Amer. J. Physiol. 270, 1085-1091

Conconi M.T., Nico B., Guidolin D., Baiguera S., Spinazzi R., Rebuffat P., Malendowicz L.K., Vacca A., Carraro G., Parnigotto P.P., Nussdorfer G.G., Ribatti D., 2004. Ghrelin inhibits FGF2-mediated angiogenesis in vitro and in vivo. Peptides 25, 2179-2185 
Dembinski A., Warzecha Z., Ceranowicz P., Tomaszewska R., Stachura J., Konturek S.J., Konturek P.C., 2003. Ghrelin attenuates the development of acute pancreatitis in rat. J. Physiol. Pharmacol. $54,561-573$

Drucker D.J., 2003. Glucagon-like peptides: regulation of cell proliferation, differentiation and apoptosis. Mol. Endocrinol. 17, 161-171

Fholenhag K., Malmlof K., Skottner A., Nyberg F., 1999. Effects of human growth hormone on the porto-arterial concentration differences of glucose and amino acids in the newborn piglet. Hormone Metab. Res. 31, 22-26

Fuglsang J., Skjaerbaek C., Espelund U., Frystyk J., Fiszer S., Flyvbjerg A., Olsen P., 2005. Ghrelin and its relationship to growth hormonem during normal pregnancy. Clin. Endocrinol. 62, 554-559

Godlewski M.M., Słupecka M., Woliński J., Skrzypek T., Skrzypek H., Motyl T, Zabielski R., 2005. Into the unknown - the death pathways in the neonatal gut epithelium. J. Physiol. Pharmacol. 56, Suppl. 3 (in press)

Gordon P.V., Paxton J.B., Herman A.C., Carlisle E.M., Fox N.S., 2004. Igf-I accelerates ileal epithelial cell migration in culture and newborn mice and may be a mediator of steroid-induced maturation. Pediat. Res. 55, 34-41

Hardin J.A., Buret A., Meddings J.B., Gall D.G., 1993. Effect of epidermal growth factor on enterocyte brush-border surface area. Amer. J. Physiol. 264, G312-G318

Hardin J.A., Wong J.K., Cheeseman C.I., Gall D.G., 1996. Effect of luminal epidermal growth factor on enterocyte glucose and proline transport. Amer. J. Physiol. 271, G509-G515

Helmrath M.A., Shin C.E., Erwin C.R., Warner B.W., 1998. The EGF inverted question markEGFreceptor axis modulates enterocyte apoptosis during intestinal adaptation. J. Surg. Res. 77, 17-22

Hosoda H., Kojima M., Kangawa K., 2002. Ghrelin and the regulation of food intake and energy balance. Mol. Interv. 2, 494-503

Houle V.M., Schroeder E.A., Odle J., Donovan S.M., 1997. Small intestinal disaccharidase activity and ileal villus height are increased in piglets consuming formula containing recombinant human insuline-like growth factor-I. Pediat. Res. 42, 78-86

Houle V.M., Park Y.K., Laswell S.C., Freund G.G., Dudley M.A., Donovan S.M., 2000. Investigation of three doses of oral insulin-like growth factor-I on jejunal lactase phlorizin hydrolase activity and gene expression and enterocyte proliferation and migration in piglets. Pediat. Res. 48, 497-503

Jarboe M.D., Juno R.J., Stehr W., Bernal N.P., Profitt S., Erwin C.R., Warner B.W., 2005. Epidermal growth factor receptor signaling regulates goblet cell production after small bowel resection. J. Pediat. Surg. 40, 92-97

Kelly D., McFadyen M., King T.P., Morgan P.J., 1992. Characterization and autoradiographic localization of the epidermal growth factor receptor in the jejunum of neonatal and weaned pigs. Reprod. Fert. Develop. 4, 183-191

Kojima H., Hidaka H., Matsumura K., Fujita Y., Nishio Y., Maegawa H., Haneda M., Yasuda H., Fujimiya M., Kikkawa R., Kashiwagi A., 1998. Concerted regulation of early enterocyte differentiation by insulin-like growth factor I, insulin, and transforming growth factor-betal. Proc. Assoc. Am. Physicians 110, 197-206

Kojima M., Hosoda H., Date Y., Nakazato M., Matsuo H., Kangawa K., 1999. Ghrelin Is a GrowthHormone-Releasing Acylated Peptide From Stomach. Nature 402, 656-660

Lamprecht S.A., Schwartz B., Glicksman A., 1989. Transforming growth factor-beta in intestinal epithelial differentiation and neoplasia (review). Anticancer Res. 9, 877-881

Le Huërou I., Guilloteau P., Wicker C., Mouatas A., Chayvialle J.A., Bernard C., Burton J., Toullec R., Puigserver A., 1992. Activity distribution of seven digestive enzymes along small intestine in calves during development and weaning. Digest. Dis. Sci. 37, 40-46 
Lipkin M., Sherlock P., Bell B., 1963. Cell proliferation kinetics in the gastrointestinal tract of man.II.cell renwal in stomach, ileum, colon and rectum. Gastroenterology 45, 721 - 729

Ma L., Xu R.J., 1997. Oral insulin-like growth factor-I stimulates intestinal enzyme maturation in newborn rats. Life Sci. 61, 51-58

Maccarinelli G., Sibilia V., Torsello A., Raimondo F., Pitto M., Giustina A., Netti C., Cocchi D., 2005. Ghrelin regulates proliferation and differentiation of osteoblastic cell. J. Endocrinol. 184, 249-256

Manners M.J., Stevens J.A., 1972. Changes from birth to maturity in the pattern of distribution of lactase and sucrase activity in the mucosa of small intestine in pigs. Brit. J. Nutr. 28, 113-127

Menard D., Pothier P., 1991. Radioautographic localization of epidermal growth factor receptors in human fetal gut. Gastroenterology 101, 640-649

Morgan C.J., Coutts A.G.P., McFadyen M.C., King T.P., Kelly D., 1996. Characterisation of IGF-I receptors in the porcine small intestine during postnatal development. J. Nutr. Biochem. 7, 339 (Abstr.)

Nankervis C.A., Reber K.M., Nowicki P.T., 2001. Age-dependent changes in the postnatal intestinal microcirculation. Microcirculation 8, 377-387

Pennisi E., 2005. The dynamic gut. Science 307, 1896-1899

Petersen Y.M., Hartman B., Holst J.J., Le Huërou-Luron I., Bjornvad C.R., Sangild P.T., 2003. Introduction of enteral food increases plasma GLP-2 and decreases GLP-2 receptor mRNA abundance during pig development. J. Nutr. 133, 1781-1786

Rådberg K., Biernat M., Linderoth R., Zabielski R., Weström B.R., 2001. enteral exposure to crude red kidney been lectin induces maturation of the gut in suckling pigs. J. Anim. Sci. 79, 2669-2678

Read L.C., 1988. Milk growth factors. In: F. Cockburn (Editor). John Wiley and Sons, London, pp. 131-152

Read L.C., Upton F.M., Francis G.L., Wallace J.C., Dahlenberg G.W., Ballard F.J., 1984. Changes in the growth-promoting activity of human milk during lactation. Pediat. Res. 18, 133-139

Roeche R., 1999. Genetic determination of individual birth weight and its association with sow productivity traits using Bayesian analyses. J. Anim. Sci. 77, 330-343

Sakata I., Tanaka T., Matsubara M., Yamazaki M., Tani S., Hayashi Y., Kangawa K., Sakai T., 2002. Postnatal changes in ghrelin mRNA expression and in ghrelin-producing cells in the rat stomach. J. Endocrinol. 174, 463-471

Sanglid P.T., Trahair J.F., Loftager M.K., Fowden A.L., 1999. Intestinal macromolecule absorption in the fetal pig after infusion of colostrum in utero. Pediat. Res. 45, 595-602

Sanglid P.T., Xu R.J., Trahair J.F., 2002. Maturation of intestinal function: the role of cortisol and birth. In: R. Zabielski, P. C. Gregory, B.R. Weström (Editors). Biology of the Intestine in Growing Animals. Elsevier, Amsterdam (The Netherlands), pp. 11-144

Schober D.A., Simmen F.A., Hadsell D.L., Baumrucker C.R., 1990. Perinatal expression of type I IGF receptors in porcine small intestine. Endocrinology 126, 1125-1132

Secor S.M., Diamond J., 1995. Adaptive responses to feeding in Burmese pythons: pay before pumping. J. Exp. Biol. 198, 1313-1325

Shin E.D., Estall J.L., Izzo A., Drucker D.J., Brubaker P.L., 2005. Mucosal adaptation to enteral nutrients is dependent on the physiologic actions of glucagon-like peptide- 2 in mice. Gastroenterology 128, 1340-1353

Shulman R.J., Tivey D.R., Sunitha I., Dudley M.A., Henning S.J., 1992. Effect of oral insulin on lactase activity, mRNA, and posttranscriptional processing in the newborn pig. J. Pediat. Gastroenterol. Nutr. 14, 166-172

Sibilia V., Rindi G., Pagani F., Rapetti D., Locatelli V., Torsello A., Campanini N., Deghenghi R., Netti C., 2003. Ghrelin protects against ethanol-induced gastric ulcers in rats: studies on the mechanisms of action. Endocrinology 144, 353-359 
Simmen F.A., Cera K.R., Mahan D.C., 1990. Stimulation by colostrum or mature milk of gastrointestinal tissue development in newborn pigs. J. Anim. Sci. 68, 3596-3603

Staley M.D., Gibson C.A., Herbein J.F., Grosvenor C.E., Baumrucker C.R., 1998. Rat milk and dietary long arginine 3 insulin-like growth factor I promote intestinal growth of newborn rat pups. Pediat. Res. 44, 512-518

Steeb C.B., Shoubridge C.A., Tivey D.R., Read L.C., 1997. Systemic infusion of IGF-I or LR3IGFI stimulates visceral organ growth and proliferation of gut tissues in suckling rats. Amer. J. Physiol. 272, G522-G533

Svendsen L.S., Weström B.R., Svendsen J., Ohlsson B.G., Ekman R., Karlsson B.W., 1986. Insulin involvement in intestinal macromolecular transmission and closure in neonatal pigs. J. Pediat. Gastroenterol. Nutr. 5, 299-304

Tannenbaum G.S., Epelbaum J., Bowers C.Y., 2003. Interrelationship between the novel peptide ghrelin and somatostatin/growth hormone-releasing hormone in regulation of pulsatile growth hormone secretion. Endocrinology 144, 967-974

Thompson J.S., 1999. Epidermal growth factor inhibits somatostatin-induced apoptosis. J. Surg. Res. 81, 95-100

Torp N., Rossi M., Troelsen J.T., Olsen J., Danielsen E.M., 1993. Lactasephlorizin hydrolase and aminopeptidase $\mathrm{N}$ are differentialy regulated in the small intestine of the pig. Biochem . J. 295, $177-182$

Torsello A., Luoni M., Schweiger F., Grilli R., Guidi M., Bresciani E., Deghenghi R., Muller E.E., Locatelli V., 1998. Novel hexarelin analogs stimulate feeding in the rat through a mechanism not involving growth hormone release. Eur. J. Pharmacol. 360, 123-129

Trahair J.F., Sangild P.T., 1997. Systemic and luminal influences on the perinatal development of the gut. Equine Vet. J., Suppl. 24, 40-50

Tungthanathanich P., Xu R.J., Reynolds G.W., Simpson H.V., Mellor D.J., 1992. The effects of milk diets on small intestinal growth in newborn piglets. Proc. Nutr. Soc.- N.Z. 17, 51 (Abstr.)

Wang T., Xu R.J., 1996. Effects of colostrum feeding on intestinal development in newborn pigs. Biol. Neonate 70, 339-348

Weström B.R., Ekman R., Svendsen L., Svendsen J., Karlsson B.W., 1987. Levels of immunoreactive insulin, neurotensin, and bombesin in porcine colostrums and milk. J. Pediat. Gastroenterol. Nutr. 6, 460-465

Widdowson E.M., Colombo V.E., Artavanis C.A., 1976. Changes in the organs of pigs in response to feeding for the first $24 \mathrm{~h}$ after birth. II The digestive tract. Biol. Neonate 28, 272-281

Woliński J., 2003. Role of colostrum and milk leptin on the development of the gastrointestinal tract structure and function in new born pigs (in Polish). PhD. Thesis, The Kielanowski Institute of Animal Physiology and Nutrition, Polish Academy of Sciences, Jabłonna

Woliński J., Biernat M., Guilloteau P., Weström B., Zabielski R., 2003. Exogenous leptin controls the development of the small intestine in neonatal piglets. J. Endocrinol. 177, 215-222

Woliński J., Leśniewska V., Biernat M., Bąbelewska M., Korczyński W., Zabielski R., 2001. Exogenous leptin influences gastrointestinal growth and in vitro small intestinal motility in neonatal piglets - preliminary results. J. Anim. Feed Sci. 10, Suppl. 2, 249-254

Xu R.J., Mellor D.J., Tungthanathanich P., Birtles M.J., Reynolds G.W., Simpson H.V., 1992. Growth and morfological changes in the small intestine in piglets during the first three days after birth. J. Develop. Physiol. 18, 161-172

Yoshihiro N., Hiejima H., Mifune H., Sato T., Kangawa K., Kojima M., 2005. Developemental changes in the pattern of ghrelin's acyl modyfication and the levels of acyl-modified ghrelins in murine stomach. Endocrinology 146, 2709-2715 
Zhang H., Malo C., Buddington R.K., 1997. Suckling induces rapid intestinal growth and changes in brush border digestive functions of newborn pigs. J. Nutr. 127, 418-426

Ziv E., Bendayan M., 2000. Intestinal absorption of peptides through the enterocytes. Microsc. Res. Technique 49, 346-352

\section{STRESZCZENIE}

\section{Żywieniowa i hormonalna kontrola przebudowy nablonka jelita u nowonarodzonych prosiąt}

Pierwsze kilka dni po urodzeniu ssaków są znaczące dla rozwoju przewodu pokarmowego. W rozwoju, szczególnie nabłonka jelita, rozróżnia się procesy wzrostowe i związane z dojrzewaniem. Największe znaczenie mają pierwsze 24 godziny, podczas których następuje masywna przebudowa komórek nabłonkowych połączona z ich intensywną wymianą. W tym czasie przewód pokarmowy noworodków dostosowuje się do żywienia enteralnego i uczy się nowych funkcji. W siarze i w mleku stężenie hormonów i czynników wzrostowych jest wysokie; stymulują one błonę śluzową jelita do wzrostu i dojrzewania. Podawanie preparatów mlekozastępczych, które pozbawione są bioaktywnych czynników wzrostowych, prowadzi do znacznego spowolnienia procesów przebudowy tkanek jelita. Badania ostatnich lat wskazują na istotny wpływ pokarmowych, hormonalnych, parakrynnie i autokrynnie uwalnianych czynników w procesach proliferacji i różnicowania komórek nabłonka jelitowego. 